\title{
What are the dimensions of thinking skills in Turkish literature: a content analysis study?
}

\author{
Yalçın Dilekli \\ Department of Educational Science, Aksaray University, Turkey
}

\begin{tabular}{l}
\hline \hline Article Info \\
\hline Article history: \\
Received Dec 12, 2018 \\
Revised Feb 14, 2019 \\
Accepted Feb 25, 2019 \\
\hline
\end{tabular}

Keywords:

Content analyses

Thinking skills

Turkish literature

\begin{abstract}
New world needs thinking generation. However, growing thinking generation is very difficult because there are many discrepancies in defining of thinking and thinking skills. Without defining thinking and its dimensions, it is nearly impossible to grow such generation. For having thinking generation, thinking and its dimensions should be described. In the past 20 years, there have been many different definitions with regard to thinking and thinking skills. But, three different approaches for defining thinking skills and needed basic cognitive operations were commonly accepted. Aim of this study whether these three approaches for defining thinking skills were accepted in Turkish literature or not. For this aim, 14 studies, selected from Turkish database, related to thinking skills were analyzed. According the content analysis results, Turkish literature follows these three movements for defining thinking skills except for belonging to specific areas.
\end{abstract}

Copyright (C) 2019 Institute of Advanced Engineering and Science. All rights reserved.

\section{Corresponding Author:}

Yalçın Dilekli,

Department of Educational Science, Curriculum and Instruction,

Aksaray University,

Adana Yolu, Kampus, 68100, Aksaray, Turkey.

Email: dilekliyalcin@gmail.com

\section{INTRODUCTION}

Teaching thinking has become a slogan for more than three decades for educators. In order to reach this goal, many countries have changed their curriculums [1]-[11]. However, dimensions of the thinking skills or what should be thought for thinking generations has not been decided. Up to 1990s, thinking skills has not been clearly defined. After that the main three approaches for defining thinking skills emerged. The first one is Costa's [12]. In order to define thinking skills, Costa collected data from 60 experts and labelled dimensions of thinking skills as critical thinking, problem solving, creativity and decision making in the study "Developing Minds: A Resource Book for Teaching Thinking" [1], [12]. The second definition is by [13], [14] whose definitions have one more dimension for thinking skills.

\subsection{Critical thinking}

Critical thinking is purposeful, self-regulatory judgment which results in interpretation, analysis, evaluation, inference, synthesis, and evaluation of the concepts. This judgment is based on explanation of the evidential, conceptual, methodological, contextual considerations [15]-[18]. Therefore, critical thinker has the capacity of making predictions and formulating hypotheses, distinguishing fact from the opinion, determining bias reliability of evidence, relating causes and effects, being honest in facing personal biases, willing to reconsider, being reasonable in the selection of criteria, avoiding to reach premature conclusions, searching for meaning, determining the real aim, revisiting the alternatives and data processing [15]-[22].

\subsection{Problem solving}

Problem solving is the second dimension of thinking skills. It is an attempt to reach previously defied goal. In order to be a problem solver, one should break the problem into manageable parts, using 
special cases, and working backwards [23]. Problem solvers identify which pieces of data are relevant when faced with a mass of data, construct relationships between data and reach new solution/s, collect new data for new options, compare the options and decide one or more solutions for the defined goal [24]. Besides, good problem solvers are generally creative and flexible people and scientific reasoning, evaluating options and data processing [1], [14], [19], [22], [23]. Problem solving starts with identifying the problem and then continues generating and assessing possible solutions and implementing the problems. In all these steps, problem solvers need critical thinking [14], [20], [23].

\subsection{Creativity}

Creativity is another dimension. It is act of synthesis or gathering thoughts in order to get new or different ideas or to find hidden patterns, to find correlations between seemingly unrelated phenomena, and to generate solutions; namely, it is generating ideas for solving a problem or reaching previously defined goals [5], [14], [20]. Creative people have different perspectives than others and ready to take risks and use ordinary tools in unusual ways to solve problems or reach their goals [1], [2]. Creativity requires flexibility and being playful with ideas. Creative people are also good problem solvers. So, creative people have most of the qualification of problem solvers.

\subsection{Decision making}

Decision making is last dimension of thinking skills in [12]. Decision making is closely related to problem solving; in fact, the distinction between the two is sometimes hard to make. Decision making is centrally concerned with the process by which alternatives are evaluated and options selected for getting an aim, namely it is a kind of weighing up pros and cons [24], [25]. For good decision making, one should identify why this decision is needed, which means identifying the problem (analyses), generating options (synthesis), preparing a plan, predicting likely results or options, choosing one of these options and reanalyzing this preference [19], [22]. If one wants to reach the best decision, she/he needs to be aware of available choices. So, good decision makers are also creative and good problem solver ones.

The second definition belongs to [13]. In this definition, thinking skills has five dimensions as looking for meaning, critical thinking, problem solving, creativity and decision making. Apart from [12], one more dimension, looking for meaning [13]. This dimension includes such cognitive skills as; sequencing, ordering, ranking, comparing and contrasting, classifying, analyzing, identifying parts and holes, finding patterns and relations [7], [13]. In this classification, these entire five dimensions are related to metacognitive skill which includes planning, monitoring, redirecting and evaluating (Figure 1).

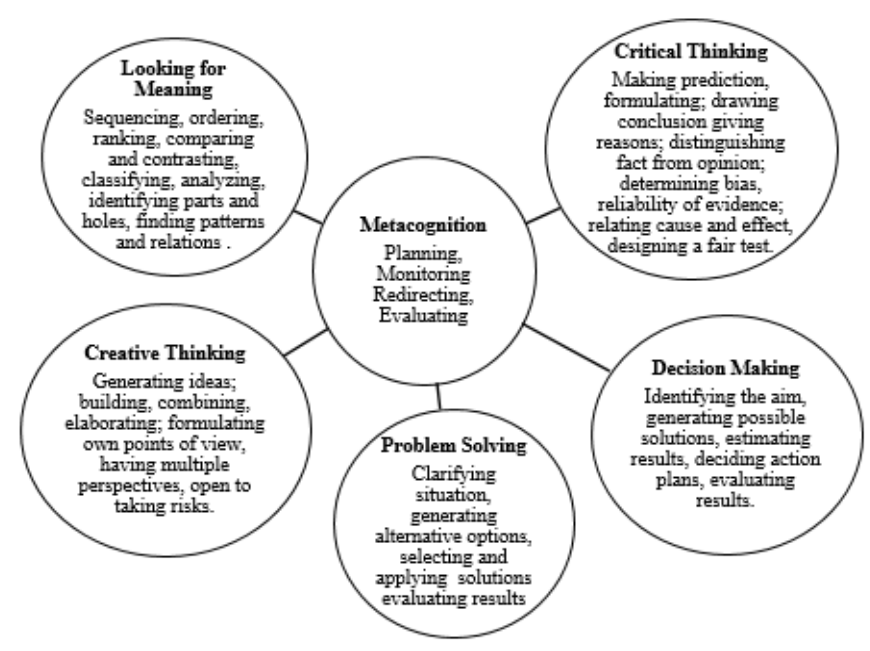

Figure 1. ACTS II sustainable thinking classrooms [13]

The third common definition is done by Swartz and Parks [14]. In their definition, the four major dimensions are indicated, critical thinking, problem solving, creativity and decision making and one more dimension called as clarification and understanding is also added [12], [13]. Under the clarification and understanding dimension, there are some cognitive skills such as comparing and contrasting, classification, sequencing under the analyzing ideas and finding relations, uncovering assumptions under analyzing

What are the dimensions of thinking skills in Turkish literature: a content analysis study? (Yalçın Dilekli) 
argument [14]. However, in this framework creative, critical thinking and clarification and understanding skills are at the bottom level of the flow chart of thinking skills. These three are inevitable steps for reaching the second step where making decision or problem solving dimensions are found (Figure 2).

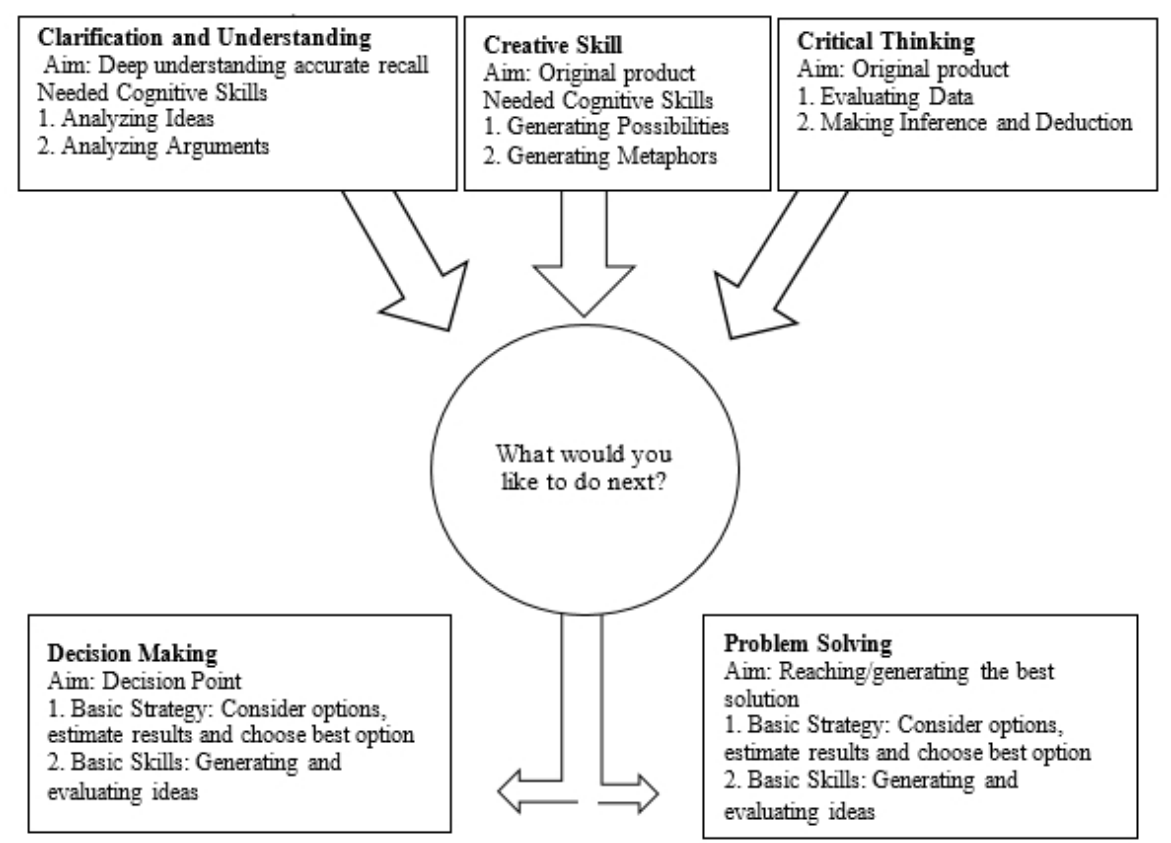

Figure 2. Infusing the teaching of critical and creative thinking into content instruction [14]

In fact, all of these dimensions are strictly connected with each other. But the results of these dimensions are different from each other. Critical thinking is concerned with critical examination and evaluation of beliefs or actions. Critical thinkers make judgment based on reliable data. Creative thinking is concerned with thinking that is unusual or original. Critical thinking involves the production of some kinds of complex product. Critical thinking and creative thinking overlap because creative thinking requires critical thinking while generating and evaluating new and original works. Although creative thinking results in an original product, critical thinking does not. Similarly, decision making and problem solving have many mutual points. However, decision making ends with choosing one or more option/s. But, problem solving is more than choosing one of the options. It includes generating options and choosing one or more of them. From this respect, problem solving includes decision making. However, without decision making skills, problem solving may not yield with intended result. Although one generates many ways to solve the problem, she/he may not choose the best alternative. Aim of decision making is to reach decision point but problem solvers try to reach solution [1], [5].

As it was seen in Table 1, four of these dimensions of thinking skills have some mutual needed basic cognitive skills. However, the aim is different from each other. Having such mutual points causes the problem of defining thinking skills and its dimension. For this reason, aim of this study is to analyze and synthesize how thinking skills are defined in the studies during two last decades in Turkish literature.

Int. J. Eval. \& Res. Educ. Vol. 8, No. 1, March 2019: 110 - 118 
Table 1. Relationships among dimensions of the thinking skills

\begin{tabular}{|c|c|c|c|}
\hline $\begin{array}{l}\text { Dimensions of } \\
\text { thinking skills }\end{array}$ & Aim & Needed basic cognitive skills & Main relationships among the dimensions \\
\hline Critical Thinking & $\begin{array}{l}\text { To reach } \\
\text { critical } \\
\text { judgment }\end{array}$ & $\begin{array}{l}\text { Defining aim } \\
\text { Evaluating options } \\
\text { Establishing cause and effect } \\
\text { relationships } \\
\text { Making inquiry } \\
\text { Grouping, classifying and analyzing the } \\
\text { obtained data } \\
\text { Distinguishing fact from opinion } \\
\text { Drawing conclusion, logical thinking }\end{array}$ & $\begin{array}{l}\text { Problem solving: to evaluate possible } \\
\text { solutions. } \\
\text { Making decision: to check and ensure } \\
\text { reliability of the data and other } \\
\text { alternatives. } \\
\text { Creativity: to decide and formulate the aim }\end{array}$ \\
\hline Problem Solving & $\begin{array}{l}\text { To reach one or } \\
\text { more solution } / \mathrm{s} \\
\text { for the problem }\end{array}$ & $\begin{array}{l}\text { Critical thinking, data processing, } \\
\text { creative thinking, implementing of the } \\
\text { planed actions, generating alternatives, }\end{array}$ & $\begin{array}{l}\text { Critical thinking: collecting data, } \\
\text { formulating problems, establishing cause } \\
\text { and effect relationships. } \\
\text { Creativity: creating new options for the } \\
\text { problem. } \\
\text { Making decision: deciding which of the } \\
\text { options are effective }\end{array}$ \\
\hline $\begin{array}{c}\text { Creativity/Creative } \\
\text { thinking }\end{array}$ & $\begin{array}{c}\text { To reach } \\
\text { original } \\
\text { idea/product }\end{array}$ & $\begin{array}{l}\text { Critical thinking, flexibility, defining } \\
\text { options, collecting data, analyzing } \\
\text { problem, generating ideas and } \\
\text { possibilities, seeing multiple } \\
\text { perspective }\end{array}$ & $\begin{array}{l}\text { Critical thinking: evaluating new ideas or } \\
\text { product, establishing new relationships } \\
\text { among the patterns. } \\
\text { Problem solving: creativity starts from } \\
\text { problem solving } \\
\text { Decision making: Selecting one of original } \\
\text { product or idea }\end{array}$ \\
\hline Decision Making & $\begin{array}{l}\text { To select one } \\
\text { or more of the } \\
\text { alternatives }\end{array}$ & $\begin{array}{l}\text { Critical thinking, creative thinking, } \\
\text { problem solving, generating options, } \\
\text { predicting likely consequences }\end{array}$ & $\begin{array}{l}\text { Critical thinking: collecting data and } \\
\text { evaluating options. } \\
\text { Problem solving: formulating and } \\
\text { analyzing problem. } \\
\text { Creativity: proposing new alternatives. }\end{array}$ \\
\hline
\end{tabular}

\section{RESEARCH METHOD}

\subsection{Research design}

In this study, qualitative content analysis is used. Content analysis is defined as a research method for the subjective interpretation of the content of text data through the systematic classification, process of coding and identifying themes or patterns. In this research directed content analysis approach was chosen because the goal of a directed approach to content analysis is to validate a theoretical framework or theory [26].

\subsection{Coding process}

Firstly, related parts of each study included in the research were read in details and noted and grouped according to the indicated cognitive skills according to the dimensions. Later, indicated cognitive skills overlapping in more than one dimension were identified. Furthermore, each study was coded as K1, K2 ... K14 and these codes were used in the research.

\subsection{Validity and reliability of the research}

For validity and reliability during the coding process, studies were examined by two expert academicians one of whom was an expert on assessing and evaluation in education and the other was an expert on educational sciences.

\subsection{Data collection and inclusion criteria}

In this study 14 researches were selected form the Turkish data base called Turkish Academic Network and Information Center (ULAKBIM). ULAKBİM data base covers the journals published in Turkey. However, ULAKBİM has strict selection criteria for indexing the journals, such as publication history, transparent reviewing process, at least having extended abstract in second language and some other criteria related to formatting. For collecting data 'thinking skills, higher ordering thinking skills' terms were used both in Turkish and English. In the first step, 872 studies were listed including these two terms. Firstly, title of the studies was analyzed. As this study aimed at the definition of thinking skills as a whole, 727 studies including only one dimension of thinking skills such as critical thinking or scientific thinking skills were excluded. The rest 145 researches' summaries were analyzed in the second step. At this step, 113 studies were excluded again as all dimensions of thinking skills weren't defined or being related to computational thinking, thinking in drama and art. In the final step, 18 studies were excluded after the analyzing the whole study because of lacking of well-grounded definition or defining only one or two

What are the dimensions of thinking skills in Turkish literature: a content analysis study? (Yalçın Dilekli) 
dimensions of thinking skills dimensions. At the end, totally 14 researches, 9 of them were qualitative and 5 of them quantitative, were found including thinking skills dimensions for defining thinking skills. Researches on thinking skills included in this study were shown in Table 2.

Table 2. Researches on thinking skills included in the study

\begin{tabular}{|c|c|c|}
\hline Study Code & Study Name & Method \\
\hline K1 & $\begin{array}{l}\text { Temel, S., Dinçol Özgür, S. \& Y1lmaz, A. (2012). The effect of learning cycle model on } \\
\text { preservice chemistry teachers' understanding of oxidation reduction topic and thinking skills. } \\
\text { Necatibey Faculty of Education Electronic Journal of Science and Mathematics Education, Vol. } \\
6(1), 287-305 \text {. }\end{array}$ & $\begin{array}{l}\text { Quantitative } \\
\text { study }\end{array}$ \\
\hline $\mathrm{K} 2$ & $\begin{array}{l}\text { Gelen, İ. (2011). Determination of the level of acquisition of some common skills concerning } \\
\text { thinking in the curriculum of social studies. Ondokuz Mayı Üniversitesi Ë̆itim Fakültesi Dergisi, } \\
\text { Vol. } 30(1), 83-106 \text {. }\end{array}$ & $\begin{array}{l}\text { Quantitative } \\
\text { study }\end{array}$ \\
\hline $\mathrm{K} 3$ & $\begin{array}{l}\text { Ekinci, N. \& Canses, T. (2017). Classroom teachers' epistemological beliefs and their classroom } \\
\text { practices for teaching thinking skills. İnsan ve Toplum Bilimleri Araştırmaları Dergisi, Vol. 6(3), } \\
1747-1773 \text {. }\end{array}$ & $\begin{array}{l}\text { Quantitative } \\
\text { study }\end{array}$ \\
\hline K4 & $\begin{array}{l}\text { Tok, E. \& Sevinç, M. (2010). The effects of thinking skills education on the critical thinking and } \\
\text { problem solving skills of preschool teacher candidates. Pamukkale Üniversitesi Eğitim Fakültesi } \\
\text { Dergisi, Vol. } 27,67-82 \text {. }\end{array}$ & $\begin{array}{l}\text { Quantitative } \\
\text { study }\end{array}$ \\
\hline K5 & $\begin{array}{l}\text { Yenilmez, K. (2011). In-service and pre-service mathematics teachers' opinions about teaching of } \\
\text { thinking skills. Educational Research Association the International Journal of Research in } \\
\text { Teacher Education, Vol. 2(3), 17-28. }\end{array}$ & $\begin{array}{l}\text { Quantitative } \\
\text { study }\end{array}$ \\
\hline K6 & $\begin{array}{l}\text { Aydın, F. (2011). Evaluation of high school geography course in terms of thinking skills. Eastern } \\
\text { Geographical Review, Vol.25, 162-182. }\end{array}$ & $\begin{array}{l}\text { Quantitative } \\
\text { study }\end{array}$ \\
\hline K7 & $\begin{array}{l}\text { Mutlu, E. \& Aktan, E. (2011). Okul öncesi öğretmenlerinin düşünme eğitimi ile ilgili tutumlarının } \\
\text { incelenmesi. Türk Ĕ̈itim Bilimleri Dergisi, Vol. 9(4), 799-830. }\end{array}$ & $\begin{array}{l}\text { Quantitative } \\
\text { study }\end{array}$ \\
\hline K8 & $\begin{array}{l}\text { Aslan, S. (2017). An investigation of primary school teachers' perceptions of self- efficacy } \\
\text { towards teaching thinking skills in terms of several variables. PAU Egitim Fakültesi Dergisi, } \\
\text { Vol.41, 61-73. }\end{array}$ & $\begin{array}{l}\text { Quantitative } \\
\text { study }\end{array}$ \\
\hline K9 & $\begin{array}{l}\text { Ülger K. (2015). Sanat eğitiminin düşünme becerileri üzerine etkisi. Milli Eğitim, Vol. } 206 \text { (2), } \\
\text { 135-147. }\end{array}$ & $\begin{array}{l}\text { Quantitative } \\
\text { study }\end{array}$ \\
\hline K10 & $\begin{array}{l}\text { Baysal Z. N., Çarıçç, S., \& Yaşar, E. B. (2016). Classroom teachers' awareness of teaching } \\
\text { thinking skills. Eğitimde Nitel Araştırmalar Dergisi - Journal of Qualitative Research in } \\
\text { Education, Vol. 5(1), 7-28. }\end{array}$ & Qualitative Study \\
\hline K11 & $\begin{array}{l}\text { Büyüktaşkapu Soydan, S. \&, Dereli, H. M. (2014). A comparative examination of strategies } \\
\text { aiming to improve thinking skills of children used by preschool teachers in different countries. } \\
\text { Kastamonu Eğitim Dergisi, Vol. 22(2), 475-496. }\end{array}$ & Qualitative Study \\
\hline K12 & $\begin{array}{l}\text { Akbaba, A. \& Kaya, B. (2015). Teachers' opinions about cognitive skills development of children } \\
\text { at kindergarten. Elektronik Sosyal Bilimler Dergisi (Electronic Journal of Social Sciences), Vol.14 } \\
\text { (55), 148-160. }\end{array}$ & Qualitative Study \\
\hline K13 & $\begin{array}{l}\text { Doğan Altun, Z. \& Ekinci Vural, D. (2017). Thinking skills in early childhood: teachers' } \\
\text { perspective. The Journal of Buca Faculty of Education, Vol. 44, 214-224. }\end{array}$ & Qualitative Study \\
\hline K14 & $\begin{array}{l}\text { Akbiyık, C. \& Kalkan AY, G. (2014). Perceptions' of Pre-school administrators and teachers on } \\
\text { thinking skills instruction: A case study. Hacettepe Üniversitesi Ĕgitim Fakültesi Dergisi (H. U. } \\
\text { Journal of Education), Vol. 29(1), 01-18. }\end{array}$ & Qualitative Study \\
\hline
\end{tabular}

\section{RESULTS AND DISCUSSION}

After the analyses of 14 articles, 23 cognitive skills were found and labelled under the 4 dimensions but five cognitive skills were not included in neither [12], [14], [19], frame work related to thinking skills dimesions. These dimensions and cognitive skills are given in Figure 3.

According to Figure 3, 23 different cognitive skills were used to define thinking skills. Except one study (K1) critical thinking (shown in red) and problem solving dimensions were defined as thinking skill referring the studies of [12]-[14], [27]. Creativity/creative thinking was defined another dimension of thinking skills in thirteen researches (K2, K3, K4, K5, K6, K7, K9, K12, K13, K14) [7], [28]. In the research reports, decision-making skill, labeled as one of the dimensions of the thinking skills in five researches (K7, $\mathrm{K} 8, \mathrm{~K} 10, \mathrm{~K} 11, \mathrm{~K} 13)$. In two (K8, K11) of these five studies cited, [28], in one (K7) of them cited [29] again in one (K10) of these five studies cited McGuiness [7] and in one (K13) of these five studies cited Burke, [30] for defining thinking skills. These four dimensions had the highest frequency. 


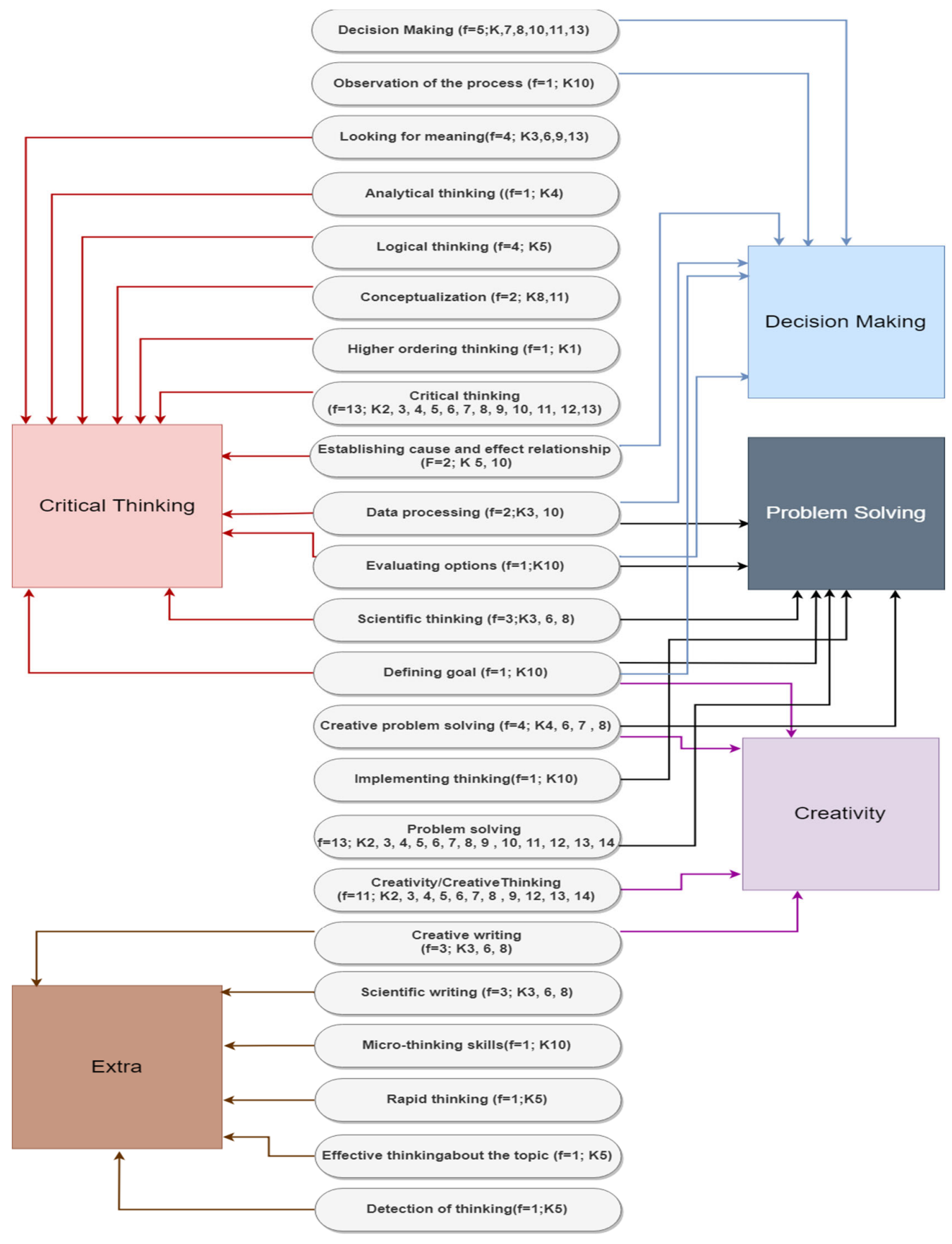

Figure 3. Dimensions of thinking skills and related cognitive skills the teaching

Other skills, looking for meaning in the studies coded as $\mathrm{K} 3, \mathrm{~K} 6, \mathrm{~K} 8, \mathrm{~K} 13$, scientific thinking, creative writing and scientific writing $\mathrm{K} 3, \mathrm{~K} 6, \mathrm{~K} 8$, creative problem solving in $\mathrm{K} 3$, $\mathrm{K} 6$, $\mathrm{K} 7$, and $\mathrm{K} 8$ were accepted as the dimensions of thinking skills by citing the definition of thinking skills [29]. Data processing and evaluating options (K8, K10), implementing thinking and defining goal, observation of the process/implementation (K10) were defined as the component of thinking skills [7]. Micro thinking skills (K11), conceptualization (K8, K11) were labelled as a part of thinking skill [28]. Rapid thinking, effective thinking about the topic, detection of thinking, logical thinking (K5) were defined as thinking skills [31]-[34]. Establishing cause and effect relationship is one of the other skill accepted as thinking skills (K5, K10) [7], [31]-[34]. Analytical thinking was defined as one of the component of thinking skills in K4 [35]. Higher

What are the dimensions of thinking skills in Turkish literature: a content analysis study? (Yalçın Dilekli) 
ordering thinking skills were accepted as thinking (analyzing, synthesizing and evaluating) skills in one study (K1) [36].

In these studies, decision making, observation of the process, establishing cause and effect relationship, data processing, evaluating options, defining goal called as cognitive skills and collected under the decision making theme $(\mathrm{K} 5, \mathrm{~K} 7, \mathrm{~K} 8, \mathrm{~K} 10, \mathrm{~K} 11, \mathrm{~K} 13)$. In nine studies, there weren't found any cognitive skills related to decision making domain.

Under the problem solving theme (shown in black) seven cognitive skills as data processing, evaluating options, scientific thinking, creative problem solving, implementing thinking, problem solving and defining goal were collected (K2, K3, K4, K5, K6, K7, K8, K9, K 10, K11, K12, K13, K14). It wasn't found any term or cognitive skill related to problem solving in one study (K1). Under creativity/creative thinking dimension, (shown in purple) four cognitive skills defining goal, creative problem solving, creativity/creative thinking and creative writing were collected $(\mathrm{K} 3, \mathrm{~K} 6, \mathrm{~K} 7, \mathrm{~K} 8, \mathrm{~K} 10)$. Creativity or creative thinking was taken into account in five studies for defining thinking skills. The rest ten studies did not include any terms which may be related to this skill. Critical thinking skill (shown in red) was found as a most common term in the definitions of the thinking skills. In all fourteen studies, eleven cognitive skills were directly or indirectly collected under the critical thinking skills. These cognitive skills were looking for meaning, higher ordering thinking (analyzing, synthesis, evaluating) analytical thinking, logical thinking, conceptualization, higher ordering thinking, critical thinking, establishing cause and effect relationship, data processing, evaluating options, scientific thinking defining goal. In the definition of thinking skills (shown in brown), scientific writing, micro thinking skills, rapid thinking, effective thinking about the topic, and detection of thinking were labelled as thinking skills; however, as these cognitive skills weren't defined in detail, they were collected under the extra skills theme (K3, K5, K6, K8, K11). Under the decision making (shown in blue) skills six skills were collected, but four of them were overlapped more than one dimension.

Besides, some cognitive skills were overlapped more than one dimension. Establishing cause and effect relationship was shared by two dimensions, making decisions and critical thinking. Scientific thinking skill was shared by two dimensions, problem solving and critical thinking. Data processing and evaluating options were shared by three dimensions as critical thinking, problem solving and making decision. Creative problem solving was labelled under both creativity and problem solving. And defining goal was shared by four dimensions as decision making, critical thinking, decision making and creativity. Creative writing and creativity were collected under creativity domain.

As it is stated in many studies, defining thinking skills is still very difficult and there is no concreate idea commonly shared by most of the experts in the world [1], [2], [6], [7], [16], [26], [37]. For example, Costa defined four main dimensions as creativity, problem solving, critical thinking and decision making and cognitive skills for each of them. On the other hand, one more main dimension called searching for meaning likewise clarification and understanding dimension [13], [14]. These two frame works [29], which has many mutual points with these two, were generally accepted by in Turkish literature. Thinking skills in five main dimensions as searching for meaning, creative thinking, critical thinking, problem solving and decision making and they add cognitive skills; for example, data processing under the critical thinking, defining goal under the decision making [13], [14]. However, in Turkish literature these cognitive skills weren't collected under main skills such as critical or creative thinking. Furthermore, in K5 and K11, which were based on thinking skills for special disciplines, the new cognitive skills scientific writing, micro thinking skills, rapid thinking, effective thinking, detection thinking were accepted as a part of thinking skills. Except in one study (K1) critical thinking skill was accepted thinking skills. In K1, analyses, syntheses and evaluation were accepted as thinking skills. In fact, these cognitive skills are accepted as the part of critical thinking [38]. So, we can say that all studies accepted critical thinking as thinking skill. Problem solving is the most second item used to describe to thinking skill. These two findings are similar to generally preferred description of thinking skills. Creativity is another term commonly used to describe thinking skills. Although decision making is indicated as thinking skill in three accepted frameworks [12]-[14], in Turkish literature only five researches described decision making as thinking skills. Instead of including decision making in the description, these studies included cognitive skills of decision making such as data processing, defining goal. In four studies, looking for meaning was defined as thinking skills [14], [19]. Scientific and creative writing were two other terms used to describe thinking skills [29]. Critical thinking and problem solving were the most two terms which were included in the definition of thinking skills and five cognitive skills were mutually mentioned in both dimensions. Establishing cause and effect relationship skill was mutually collected under two dimensions as critical thinking and decision making. Data processing, evaluating options, scientific thinking and defining goal cognitive skills were labelled under three skills as critical thinking, decision making and problem solving theme. These skills were shared by three dimensions depending on the aim. Whether individual's aim is to decision making, problem solving or critical thinking, he/she should use these cognitive skills. Critical thinking is at the top in all studies. Because, for making decision, being 
creative or problem solving one needs to collect and process data, establish cause and effect relationships which are the basic cognitive skills of critical thinking. From this respect critical thinking may be called as the first step of thinking. Other cognitive skills or thinking skills dimension change in respect for the aim. Namely, the difference of the cognitive skills classification may be because of the reaching point at the end of the process. The codes, scientific writing, micro thinking skills, rapid thinking, effective thinking about the topic, detection of thinking, collected under the theme extra. When these studies analyzed, this researches focus on the very specific ability in math discipline. From this respect, it can be said that transfer of these abilities to different disciplines or very specific areas is possible. This result is similar to Siegel [39].

\section{CONCLUSION}

As a conclusion, describing thinking skill and its dimensions generally have mutual points with common frameworks in Europe and America, but cognitive skills related to thinking skills dimensions were classified differently in different studies. These differences among these studies support final aim of this study. Furthermore, some cognitive skills differentiate for specific fields in some studies in Turkish literature.

\section{REFERENCES}

[1] Dilekli, Y., "The relationship among teachers 'classroom practices for teaching thinking skills, teachers' selfefficacy towards teaching thinking skills and teachers' teaching styles," Unpublished PhD. Dissertation, Ballkesir University, Turkey, 2015.

[2] Dilekli, Y. and Tezci, E., "The relationship among teachers' classroom practices for teaching thinking skills, teachers' self-efficacy towards teaching thinking skills and teachers' teaching styles," Thinking Skills and Creativity, vol. 21, pp. 144-151, 2016.

[3] Dilekli, Y. and Tezci, E., "Adaptation of teachers' self-efficacy towards teaching thinking skills scale into English," Journal of Education and Training Studies, vol. 6(11), pp. 260-270, 2018.

[4] Baumfield, V. and Oberski, I., "What Do Teachers Think about Thinking Skills?" Quality Assurance in Education, vol. 6(1), pp. 44-51, 1998.

[5] Hashim, H., "Malaysian teachers' attitudes, competency and practices in teaching thinking," Intellectual Discourse, vol. 11(1), pp. 27-50, 2004.

[6] Johnson, S., "Teaching Thinking Skills. (Ed. Winch, C.)," Teaching Thinking: Key Debates in Educational Policy, pp. 109-112, London. UK: Continium Press, 2010.

[7] McGuinness, C., "From Thinking Skills to Thinking Classrooms," DfEE Publications, Nottingham: UK. [Online] [Available], https://www.education.gov.uk/publications/ standard/ publicationDetail/Page1/RB115, 1999. (Accessed: 26.11.2017).

[8] Onosko, J.J., "Barriers to the promotion of higher-order thinking in social studies," Theory \& Research in Social Education, vol. 19(4), pp. 341-366, 1991.

[9] Resnick, L. B., Nested learning systems for the thinking curriculum, Educational Researcher, vol. 39(3), pp. 183197,2010

[10] Chang, S.C., "Agnes Implementation of the 'Thinking Schools, Learning Nation' initiative in Singapore," Journal of Southeast Asian Education, vol. 2(1), pp. 3-41, 2001

[11] Sim, W.K., "Some Thoughts on 'Thoughtful Schools' in Brunei Darussalam," Journal of Southeast Asian Education, vol. 2(1), pp. 66-84, 2001.

[12] Costa, L. A., Developing Minds: A resource book for teaching thinking. ASCD. Melbourne. AU. 2001.

[13] McGuinness, C., Eakin, A., Curry, C., Bunting, B. \& Sheehy, N., "ACTS II Sustainable thinking classrooms," Queen's University Belfast, 2003.

[14] Swartz, R. and Parks, S., "Infusing the teaching of critical and creative thinking into content instruction," Pacific Grove, CA: Critical Thinking \& Software, 1994.

[15] Gokhale, A. A., “Collaborative Learning Enhances Critical Thinking," Journal of Technology Education, vol. 7(1), pp. 22-30, 1995.

[16] Facione, P. A., "Critical thinking: A statement of expert consensus for purposes of educational assessment and instruction, Research Findings and Recommendations," American Philosophical Association, Newark, Del. 1990.

[17] Doğan, N., "Measuring the critical thinking (Eleştirel düşünmenin ölçülmesi)," Cito Eğitim: Kuram ve Uygulama, vol. 22, pp. 29-42, 2013.

[18] Semerci, N., "The development of critical thinking disposition scale (CTHD): Study on the revision of validity and reliability," International Periodical for the Languages, Literature and History of Turkish or Turkic, vol. 11(19), pp. 725-740, 2016.

[19] McGuinness, C., Eakin, A., Curry, C., Bunting, B. \& Sheehy, N., "Building Thinking Skills in Thinking Classrooms: ACTS in Northern Ireland," [Online] https://www.researchgate.net/publication/228374165_Building_thinking_skills_in_thinking_classrooms_ACTS_in Northern_Ireland, 2014. (Accessed: 26.11.2017)

[20] Dilekli, Y., "The relationships between critical thinking skills and learning styles of gifted students," European Journal of Education Studies, vol. 3 (4), pp. 69-96, 2017. 
[21] Demir, M. K., "The research of fourth and fifth grade primary school students critical thinking levels in social studies lessons according to different variables, (İlköğretim dördüncü ve beşinci sınıf öğrencilerinin sosyal bilgiler derslerinde eleştirel düşünme düzeylerinin çeşitli değişkenler açısından incelenmesi)," Institute of Educational Science, Gazi University, Ankara, Unpublished PhD. Dissertation, 2006.

[22] Morzano, R. J., "Dimensions of thinking: a framework for curriculum and instruction," Association for Supervision and Curriculum Development, Alexandria, Va. 1988.

[23] Butterworth, J. and Thwaites, G., "Thinking skills critical thinking and problem solving," Cambridge University Press Cambridge, CB2 8RU, UK, 2013.

[24] Smith, G. F., "Beyond critical thinking and decision making: Teaching business students how to think," Journal of Management Education, vol. 27(1), pp. 24-51, 2003.

[25] Duschl, R.A and Wright, E., "A case study of high school teachers' decision making models for planning and teaching science," Journal of Research in Science Teaching vol. 26(6), pp. 467-501, 1989.

[26] Hsieh, H. and Shannon, S. E., "Three approaches to qualitative content analysis," Qualitative Health Research, vol. 15(9), pp. 1277-1288, 2005.

[27] Özden, Y., Learning and Teaching (Öğrenme ve Öğretme), Ankara: Pegem Yayınları, 1997.

[28] Beyer, B. K., Practical Strategies for the Teaching of Thinking, Allyn and Bacon, Neton. MA, 1987.

[29] Özden, Y., Learning and Teaching (8. Edition) (Ö̈rrenme ve Ögretme ,8. Basım). Ankara: Pegem Akademi, 2008.

[30] Burke, L. A., Williams, J. M., and Skinner, D., "Teachers' perception of thinking skills in primary curriculum," Research in Education, vol. 77, pp. 1-13, 2007.

[31] Yenilmez, K., and Ekinci, A., "Attitudes of mathematics and primary school teachers about teaching of thinking skills and effect of graduate education on these skills (Sample of Eskişehir)," II. Graduate Education Symposium, Marmara University, Institute of Educational Sciences, 26-28 September 2005, Istanbul, 2005.

[32] Serdar, B., Secondary school teachers' attitudes and opinions towards enabling students have scientific thinking, Unpublished MA thesis, Afyon Kocatepe University, Afyonkarahisar, 1998.

[33] Hayran, İ., Elementary school teachers' opinions on thinking skill and its operations, Unpublished MA thesis, Afyon Kocatepe University, Afyonkarahisar, 2000.

[34] Emer, A., Primary school teachers' opinions about teaching thinking skill (A case of Izmir), Unpublished MA thesis, Eskişehir Osmangazi University, Eskişehir, 2007.

[35] Sternberg, R.J. ve Grigorenko, E., Teaching Thinking for Successful Intelligence, U.S.A.: SkyLight Professional Development, Arlington Heights, 2000.

[36] Newman, P. M., "Higher order thinking in teaching social studies: A rationale for the assessment of classroom thoughtfulness," Journal of Curriculum Studies, vol. 22, pp. 41-56, 1990.

[37] Yenipınar, Ş. and Akgün, N., "Stratejik Yönetimin İlköğretim Kurumlarında Uygulanması," Abant İzzet Baysal Üniversitesi Ĕgitim Fakültesi Dergisi, vol. 17(2), pp. 1039-1060, 2017.

[38] Kurnaz, A., Teaching critical thinking with activities (Etkinliklerle düşünmeyi ögrretme), Konya: Eğitim Yayınevi, 2011.

[39] Siegel, H., "On Thinking Skills," Teaching Thinking: Key Debates in Educational Policy, pp. 87-90 (Ed. Winch, C.). London: UK Continium Press, 2010.

Int. J. Eval. \& Res. Educ. Vol. 8, No. 1, March 2019: 110 - 118 